\title{
A Comprehensive Review on Ocimum basilicum
}

\author{
Balakrishnan Purushothaman ${ }^{1,2}$, Ramalingam PrasannaSrinivasan ${ }^{2}$, Purushothaman \\ Suganthi ${ }^{2}$, Balu Ranganathan ${ }^{3,4}$, Jolius Gimbun ${ }^{5}$ and Kumaran Shanmugam ${ }^{1 *}$ \\ 'Department of Biotechnology, Periyar Maniammai Institute of Science \& Technology, \\ Thanjavur - 613403, Tamilnadu, India; kumarans@pmu.edu \\ 2TANBIO R\&D Solution, Periyar Technology Business Incubator, Thanjavur - 613403, \\ Tamilnadu, India \\ ${ }_{3}^{3}$ Palms Connect Sdn Bhd, Shah Alam 40460, Selangor Darul Ehsan, Malaysia \\ ${ }^{4}$ Palms Connect LLC, Showcase Lane, Sandy, UT 84094, USA \\ ${ }^{5}$ Centre of Excellence for Advanced Research in Fluid Flow (CARIFF), \\ Universiti Malaysia Pahang, Gambang 26300, Pahang Malaysia
}

\begin{abstract}
The genus Ocimum has a number of species that are used to treat different types of disorders and diseases from ancient times. In this genus, $O$. basilicum plays a vital role due to its various medicinal properties. It is universally cultivated as herbaceous, perennial plant but originated from Asian continent. O. basilicum is used as a culinary herb and also has a number of pharmacological activities to prevent or treat cardiovascular disorders, diabetes, menstrual cramps, digestive disorders, neuro-degenerated disorders and cancer. In addition to that, it has been reported for antioxidant, antimicrobial, and larvicidal activities. Chemical constituents such as linalool; eugenol; 1, 8-cineone; methyl eugenol and anthocyanins are mostly responsible for the above mentioned activities. Some traditional uses of this plant coincidences with experimental results. However, the studies conducted based on its traditional use are negligible. This review is an attempt to provide a pharmaceutical perspective of Ocimum basilicum.
\end{abstract}

Keywords: Cancer, Chemical Constituents, Immunomodulatory, Pharmacological Activity, GC-MS

\section{Introduction}

The genus Ocimum belongs to the family Lamiaceae. There are about 150 species of Ocimum ${ }^{1}$. The genus Ocimum has a number of species that are used to treat different types of ailments from ancient time, especially the species Ocimum basilicum ${ }^{2}$. It is otherwise known as sweet basil. It is a universally cultivated herbaceous, perennial plant ${ }^{3}$. It is a popular herb used in Italian and Southeast cuisines of Thailand and Vietnam ${ }^{4}$. It has numerous potent activities due to the metabolites present in it. As a consequence of its virulent metabolites, it is used in traditional medicine $\mathrm{e}^{5-6}$ and also as an ornamental plant ${ }^{7}$. The extracts of essential oils of Ocimum basilicum are used as the flavors for the food products. It is used as a kitchen herb, culinary herb and ornamental herb ${ }^{8}$. It has also been used as commercial fragrances, flavors and to improve the food products shelf life $\mathrm{e}^{9-11}$.

O. basilicum has been reported numerously in areas related to agriculture, food, and pharmacology. Hence, this review would shed more lights on different dimension of $O$. basilicum to the researchers. At the same time, the disappearance of $O$. basilicum in certain regions is increasing day by day so, it is vital to create awareness on the medicinal importance of this plant to prevent its extinction. All these things made us to pen down this review which is mainly focused on the pharmaceutical prospective of Ocimum basilicum. 


\section{Historical Perspectives}

Ayurveda and Unani physicians used this plant in various forms to cure ringworm, rashes, and other skin troubles. Since 1930, Ocimum is targeted to study the chemical combination of basil oil and also as a kitchen herb and decorative plant ${ }^{12}$. The genus Ocimum covers over 150 species of herbs in addition shrubs ${ }^{13-14}$. It is broadly used in food, pharmaceutical, cosmetic, aromatherapy and perfumery industries ${ }^{15-16}$ and used all over the world because of its sense of taste especially, in Mediterranean food court ${ }^{17}$. The infusions of Ocimum basilicum are extensively used as old style medicine to shrink plasma lipid content in Mediterranean areas ${ }^{18}$. Above 100 herbs and shrubs of genus Ocimum originated from tropical and sub-tropical region and cultivated around the world ${ }^{19}$. The taxonomical hierarchy of $O$. basilicum is shown in Table 1 .

Table 1. Taxonomical Hierarchy of O. basilicum

\begin{tabular}{ll}
\hline Kingdom & Plantae \\
\hline Phylum & Magnoliophyta \\
Class & Magnoliopsida \\
Order & Lamiales \\
Family & Lamiaceae \\
Genus & Ocimum \\
Species & basilicum \\
\hline
\end{tabular}

\section{Traditional Claims}

In Turkey, Ocimum basilicum is used as a folk medicine and traditional Uyghur medicine to prevent and treat diabetics $^{20}$ and cardiovascular disorders ${ }^{21,22}$. In Indian Siddha medicine, it is used for treating pimples on face $^{23}$. Traditionally basil has been used to treat headaches, coughs, diarrhea and kidney malfunctions ${ }^{1}$. It also used in the treatment of insect stings, snake bites and skin infections externally. In Bulgaria, it is used as a folk medicine for the treatment of aches and pains ${ }^{24}$. In Spain, it is used as a sedative ${ }^{25}$.

\section{Perfumery}

The ethanolic steam distillation extract of flowers is used as pleasant smelling compound in perfumes ${ }^{26}$. The presence of essential oils determines the aroma of the O. basilicum.

\section{Biogeography and Ecology}

Basil is a vital oil bearing herb which can be grown in various environmental conditions on a wide range of terrain. Among varied aromatic and medicinal crops, basil is one of the crops for utilization of sodic wasteland owing towards its tolerance to higher salt, $\mathrm{pH}$ and exchangeable sodium percentage ${ }^{28}$. Hence, O. basilicum habitation varies from tropical areas of Asia, Africa, Central and south America ${ }^{1}$ but it is highly cultivated in Iran, Japan, China and Turkey ${ }^{29}$.

\section{Phytochemical Studies}

O. basilicum majorly contains about 20 compounds such as linalool, estragole, methyl eugenol, 1, 8-cineole, etc., which has been identified by GC-MS ${ }^{30}$. Camphor, limonene, thymol, citral, $\alpha$-linalool, $\beta$-linalool, estragole, are the monoterpene's of $O$. basilicum. Methyl eugenol is the active compound of Ocimum basilicum. Chichoric acid was found in the fresh basil leaves ${ }^{31}$. Crude extract of various morphological parts of Ocimum are rich in phenolics. The intensely purple pigment of flower is due to the presence of anthocyanins ${ }^{32}$. Linalool (52.42\%), methyl eugenol (18.74\%), 1,8-cineol (5.61\%) are the major compounds in O. basilicum which are isolated by the HPLC method ${ }^{30}$. Myrcene, borneol and neral are the minor compounds present at 5\%, 9\%, 8\% w/w respectively. Fourteen different anthocyanins have been isolated by HPLC within that 11 has cyanidin based pigments and 3 has peonidin based pigments ${ }^{32}$. It is also used in the preparation of cosmetics and perfumes. Extracts of Ocimum show strong inhibitory effects on HIV-1 reverse transcriptase and platelet aggregation ${ }^{33}$. Chemical constituents of $O$. basilicum and their biological activity are shown in Table 2 . The chemical structures of O. basilicum constituents are shown in Figure 1.

\section{Effluent Treatment}

Over 50,000 tons of diverse artificial colorants are yearly produced as of many industrialized processes and around $1-10 \%$ of them are settled into the surroundings ${ }^{84}$. Due to synthetic source and compound molecular structure, dyes are challenging to biodegrade when at large to the environment and their half-finished degradation frequently produces toxic compounds ${ }^{85}$. There are 
<smiles>C=CC(C)(O)CCC=C(C)C</smiles>

(A)<smiles>C=CCc1ccc(O)c(OC)c1</smiles>

(B)<smiles>CC12CCC(C1)C(C)(C)CC2</smiles>

(C)<smiles>C=CCc1ccc(OC)c(OC)c1</smiles>

(D)<smiles>C=C(C)C1CC=C(C)CC1</smiles>

(E)<smiles>C=CC1(C)CCC(C(=C)C)CC1C(=C)C</smiles>

(F)<smiles>CC(C)=CCC[C@]1(C)C2CC=C(C)[C@H]1C2</smiles><smiles>CC(=O)O[C@H]1CC2CCC1(C)C2(C)C</smiles><smiles>CC1CCC(C(C)C)C(O)C1</smiles><smiles>CC1(C)C2CCC1(Cl)C(=O)C2</smiles>

(J)<smiles>CC1=CC[C@H]2CC1CCC2C(C)C</smiles>

(K)

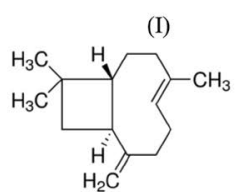

(L)<smiles>C=CC(=C)CC/C=C(\C)CCC=C(C)C</smiles>

(M)

(N)<smiles>CC1=CC[C@@H]2C(C)=CCC(C(C)C)[C@@]2(C)C1</smiles><smiles>CC(=O)OC1CC(C)CCC1C(C)C</smiles><smiles>C=C(C)C(CC)C/C=C(\C)CCC/C(C)=C/C</smiles>

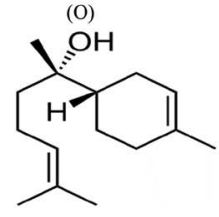

(R)
(P)<smiles>C=C(C)[C@@H]1C=C2[C@@H](CC[C@H]2C)[C@H](C)CC1</smiles>

(S)<smiles>CC1=CC2(C=C(C)C(C)=C2C)C(C(C)C)CC1</smiles>

(T)<smiles>C=CCc1ccc(OC)cc1</smiles>

(U)<smiles>C=C(C)[C@@H]1C=C2[C@H](C)CC[C@]2(C)[C@@H](C)CC1</smiles>

(W)<smiles>CC(C)[C@H]1CC[C@@H](C)C[C@H]1O</smiles>

(v)<smiles>CC(C)=C1CC[C@@H](C)CC1=O</smiles>

(X)

Figure 1. Chemical structures of (A) Linalool, (B) Eugenol, (C) 1,8-cineole, (D) Methyl eugenol, (E) Limonene, (F) $\beta$-elemene, (G) a-bergamotene, (H) Bornyl acetate, (I) Menthol, (J) Camphor, (K) a-copaene, (L) $\beta$-caryophyllene, (M) Chicoric acid, $(\mathrm{N})$ Farnesene, $(\mathrm{O}) \beta$-cadinene, $(\mathrm{P})$ Menthyl acetate, $(\mathrm{Q})$ Germacrene, (R) a-bisabolol, $(\mathrm{S}) \delta$-gurjunene, (T) $\delta$-cadinene, (U) Estragole, (V) Neo isomenthol, (W) Guaiene, (X) Pulegone. 
Table 2. Extraction methods, chemical constituents and biological activities of $\mathrm{O}$. basilicum

\begin{tabular}{|c|c|c|c|c|}
\hline S.No & $\begin{array}{l}\text { Chemical } \\
\text { constituents }\end{array}$ & Chemical class & Extraction method & Biological activity \\
\hline 1 & Linalool & Monoterpene alcohol & $\begin{array}{l}\text { Solvent free microwave } \\
\text { extraction and conventional } \\
\text { hydrodistillation }^{34}\end{array}$ & $\begin{array}{l}\text { Antihyperalgesic, } \\
\text { Antinociceptive }^{35}\end{array}$ \\
\hline 2 & Eugenol & Phenylpropanoid & $\begin{array}{l}\text { Steam } \\
\text { distillation }\end{array}$ & $\begin{array}{l}\text { Neuro-protective, Anti-cancer, } \\
\text { local anesthetic }{ }^{37}\end{array}$ \\
\hline 3 & 1,8-cineole & Monoterpenoid & Hydrodistillation ${ }^{38}$ & $\begin{array}{l}\text { Antiulcer, Wound healing } \\
\text { activity } 39\end{array}$ \\
\hline 4 & Methyl eugenol & Phenylpropene & Hydrodistillation ${ }^{40}$ & $\begin{array}{l}\text { Anticonvulsant and } \\
\text { Anesthetic }\end{array}$ \\
\hline 5 & Limonene & Monoterpene & $\begin{array}{l}\text { Solvent at high pressure high } \\
\text { temperature extraction }{ }^{42}\end{array}$ & $\begin{array}{l}\text { Motor relaxant, Anti- } \\
\text { inflammatory } 43\end{array}$ \\
\hline 6 & $\beta$-elemene & Sesquiterpenoid & Hydro and glycol distillation ${ }^{44}$ & Antineoplastic, Anticancer ${ }^{45}$ \\
\hline 7 & a-bergamotene & Sesquiterpene & Cold maceration ${ }^{46}$ & $\begin{array}{l}\text { Abiotic } \\
\text { stresses release }^{47}\end{array}$ \\
\hline 8 & Bornyl acetate & Acetate ester & $\begin{array}{l}\text { Microwave assisted } \\
\text { extraction } 48\end{array}$ & $\begin{array}{l}\text { Analgesic, Anti- } \\
\text { inflammatory }{ }^{49}\end{array}$ \\
\hline 9 & Menthol & Alcohol & Soxhlets solvent extraction ${ }^{50}$ & Local anesthetic ${ }^{51}$ \\
\hline 10 & Camphor & Terphenoid & Liquid liquid extraction 52 & $\begin{array}{l}\text { Decongesting, Antipruritic, } \\
\text { counterirritant }^{53}\end{array}$ \\
\hline 11 & a-copaene & Sesquiterpene & Supercritical fluid extraction ${ }^{54}$ & $\begin{array}{l}\text { Cytotoxic, } \\
\text { Anti-genotoxic, Antioxidant }{ }^{55}\end{array}$ \\
\hline 12 & $\beta$-caryophyllene & Sesquiterpene & Supercritical fluid extraction ${ }^{56}$ & $\begin{array}{l}\text { Antibiotic, Antioxidant, anti- } \\
\text { Carcinogenic }^{57}\end{array}$ \\
\hline 13 & Chicoric acid & Phenylpropanoid & $\begin{array}{l}\text { Solvent microwave } \\
\text { extraction } 58\end{array}$ & $\begin{array}{l}\text { Antioxidant, } \\
\text { Immunostimulatory }\end{array}$ \\
\hline 14 & Farnesene & Sesquiterpene & $\begin{array}{l}\text { Steam } \\
\text { distillation } \\
60\end{array}$ & $\begin{array}{l}\text { Anti-oxidant, Anti- } \\
\text { Insecticidal }^{61}\end{array}$ \\
\hline 15 & $\beta$-cadinene & Bicyclic sesquiterpene & $\begin{array}{l}\text { Supercritical fractioned } \\
\text { extraction }^{62}\end{array}$ & $\begin{array}{l}\text { Antinociceptive, } \\
\text { Antiproliferative }^{63}\end{array}$ \\
\hline 16 & Menthyl acetate & Monoterpene & Solid-phase microextraction ${ }^{64}$ & Antioxidant, Antibacterial ${ }^{65}$ \\
\hline 17 & Germacrene & Sesquiterpene & Solvent extraction ${ }^{66}$ & $\begin{array}{l}\text { Analgesic }{ }^{67}, \text { Anti- } \\
\text { inflammatory }\end{array}$ \\
\hline 18 & a-bisabolol & Sesquiterpene alcohol & $\begin{array}{l}\text { Supercritical carbon dioxide } \\
\text { extraction and in situ } \\
\text { extraction }^{69}\end{array}$ & $\begin{array}{l}\text { Analgesic }{ }^{70}, \text { Antibiotic }^{70}, \\
\text { Anticancer }\end{array}$ \\
\hline 19 & $\delta$-gurjunene & $\begin{array}{l}\text { Cyclo aromadendrane } \\
\text { sesquiterpenoid }\end{array}$ & $\begin{array}{l}\text { Supercritical fluid extraction } \\
\text { method }^{72}\end{array}$ & $\begin{array}{l}\text { Antitumor, Anti-inflammatory, } \\
\text { Anti-oedematous }^{73}\end{array}$ \\
\hline 20 & $\delta$-cadinene & Bicyclic sesquiterpene & $\begin{array}{l}\text { Headspace solid-phase } \\
\text { Microextraction }^{74}\end{array}$ & Antioxidant, Antimicrobial ${ }^{75}$ \\
\hline 21 & Estragole & Phenylpropene & Hydrodistillation ${ }^{76}$ & Neuronal excitability ${ }^{77}$ \\
\hline 22 & Neo isomenthol & Menthane monoterpenoid & Steam distillation 78 & Nasal sensation ${ }^{79}$ \\
\hline 23 & Guaiene & Sesquiterpene & Steam distillation ${ }^{80}$ & $\begin{array}{l}\text { Antiplatelet, Antithrombotic, } \\
\text { Aphrodisiac, Antidepressant }{ }^{81}\end{array}$ \\
\hline 24 & Pulegone & Monoterpenoid & $\begin{array}{l}\text { Salting-out assisted liquid- } \\
\text { liquid extraction } \\
82\end{array}$ & Antinociceptive $^{83}$ \\
\hline
\end{tabular}


several methods which are active to reduce the dyes ${ }^{86}$. Coagulation-flocculation is one of the furthermost effective and inexpensive processes for treatment of wastewater containing dye ${ }^{87}$. The plant-based coagulants are harmless to human health, cost effective and biodegradable ${ }^{88}$. They produce a lesser amount of sludge and do not modify $\mathrm{pH}$ of the treated water ${ }^{89}$. The Ocimum basilicum was used as a natural coagulant for the treatment of textile waste water ${ }^{84}$. The seeds obtained from this plant are also used for biosorption of copper ${ }^{90}$. The plant is also used as a potential bio-sorbent for chromium uptake with its high biosorption capacity of the seeds ${ }^{91}$. The plant is adaptable for all soil conditions, this plant also adaptable to grow in sodic soil which was proved by the bacterial isolates from the soil where it is isolated $^{91}$.

\section{Analytical Analysis}

\subsection{GC-MS}

In GC-MS, helium gas Agilent-Gas chromatography was equipped with HP-innowax fused silica capillary column $(30 \mathrm{~mm} \times 0.25 \mathrm{~mm} \text {, film thickness } 025 \mu \mathrm{m})^{29}$. The GC-MS analysis were performed with a carloErba HRGC 5160 mega gas chromatography equipped with FID and a Hitachi 2000 integrator ${ }^{15}$. For the different types of basil Automated HS-SPME of basil, volatiles was performed using a CombiPal multipurpose sampler connected to a GC-ITMS system ${ }^{92-94}$.

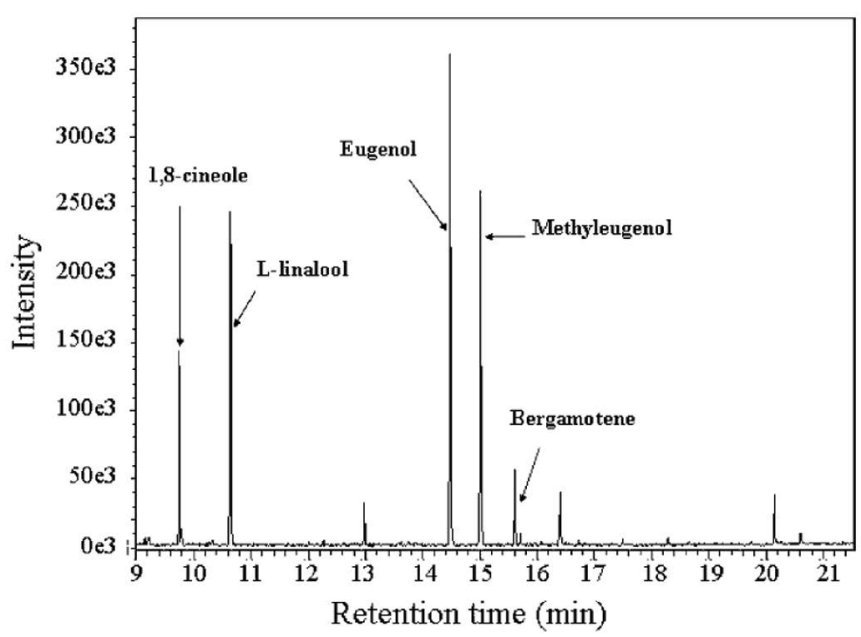

Figure 2. GC-MS image of Methyl tert-butyl ether extract of $O$. basilicum (50).
"Reprinted (adapted) with permission from Effect of Chitosan on the Biological Properties of Sweet Basil (Ocimum basilicum L.) $)^{95}$ ".

The GC-MS study (Figure 2) confirms the presence of terpenoids such as eugenol, methyl eugenol, 1, 8-cineole, L-linalool, bergamotene in the methyl tert-butyl ether extracts of $O$. basilicum at different retention time. It also reveals that the eugenol has the higher percentage (33\%) in the composition when compared with others. Identification of these compounds was done by GC-MS equipment from Shimadzu, model no: GC-17A with a DB- 5 capillary column $(60 \mathrm{~mm}-0.25 \mathrm{~mm}$, thickness 0.25 $\mu \mathrm{m})$ and the detector used was GCMS-QP 5050 mass spectrometer ${ }^{50}$.

\subsection{SEM}

A SEM study has examined the leaves at various stages of development which is dehydrated in the ethanolic series and the solvent-substituted liquid carbon-dioxide and sputter coated with gold. The material was examined using a Jeol JSM 35 SEM $^{96}$.

\subsection{HPLC}

The aqueous extract of basil has been separated to specific compounds with the help of HPLC ${ }^{21}$. The injector and detector parts of the HPLC are maintained at $523 \mathrm{~K}$ and $573 \mathrm{~K}$ respectively ${ }^{97}$. Rosmarinic acid and caffeic acid were quantified in all basil samples using a dual pump waters HPLC system ${ }^{98}$. The Identification of the essential oil compounds was based on the retention time ${ }^{99}$. It has been proved by the presence of peaks in various retention time at $280 \mathrm{~nm}$. For the above analysis, Shimadzu LC-10 AS with diode array detector (Shimadzu, SPD-10A) and the reverse phase Spherisorb ODS II (RP18), analytical column $(250 \mathrm{~mm} \times 4.6 \mathrm{~mm}$, particle size $5 \mu \mathrm{m}$ ) was used.

\section{Pharmacological Activities}

It is mostly used to treat anxiety, cold, fevers, migraines, diabetes, menstrual cramps, sinusitis, cardiovascular diseases, nerve pain, insect bites, and headache ${ }^{99-101}$. Moreover, it also acts as an anticonvulsant ${ }^{96,25}$, anti-hyperlipidemic ${ }^{102}$, anti-inflammatory ${ }^{103}$, antioxidant $^{104-105}$, antiplatelet property ${ }^{102}$, anti-thrombotic ${ }^{17}$, 
anti-microbial $^{9-11}$, insecticidal ${ }^{25}$, immunomodulatory ${ }^{106}$ and cytotoxicity effect ${ }^{107}$. It also acts against neurodegenerated disorders and digestive disorders. It is also used as cardiotonic and abdominal pain reliever ${ }^{111}$. Moreover, it also has an effect on the coccidial activity in the broiler chicks ${ }^{112}$. It also has spasmolytic, carminative, hepatoprotective, diuretic and stimulating properties that lead to the production of various drugs from Ocimum in pharma industries.

\subsection{Antimicrobial}

Numeroustherapeutic plantshave its own antimicrobial agents have gained popularity in recent years ${ }^{26}$. Due to the accidental and extensive practice of antibiotics for the action of infectious and communicable diseases, the pathogenic microorganisms remain developed into multiple disease resistance at recent years ${ }^{108}$. One of the finest methods toward to resolve this problem is to look for new therapeutic agents from plants which contain antimicrobial activities against the pathogenic microorganisms ${ }^{109}$. Extracts obtained from Ocimum basilicum has a rich source of flavor compounds and volatile oils which contain variety of compounds and these compounds possess antimicrobial activity ${ }^{106,33}$. The essential oil from $O$. basilicum is shown to have an inhibitory effect on Aspergillus ochraceus ${ }^{110}$. The hairy root cultures of Ocimum basilicum is used to achieve antimicrobial activity against bacteria and fungi by inhibiting $\mathrm{z}^{++}$ion assays in contradiction of the organisms such as $P$. aeruginosa strains (PAO1) (PA14), A, rhizogenes, $P$. fluroscens, X. campestris, E. carotovora, P. drechsleri, Phytopthora megasperma, Phytophthora parasitica, A. niger, Rhizoctoniasolani, F. oxysporum, P. aphanidermatum, P. ultimum, Versicillium dahailia, Alternaria solani and Alternaria brassicae ${ }^{111}$. The leaf extract is prepared into a powder and soaked with $95 \%$ ethanol and kept free of oil obtained from this plant also shows antimicrobial activity by ethanoic extracts from its leaves which were observed against $E$. coli and Staphylococcus aureus with its inhibition level ${ }^{26}$. Anti-fungal activity of the O. basilicum is performed in 2045 fungal species which showed more effect on the Aspergillus flavus which is toxigenic in nature ${ }^{112}$. Basil oil also has been reported for its significant effect in in vitro studies ${ }^{113}$.

\subsection{Antioxidant}

Ocimum basilicum contains several active antioxidant compounds ${ }^{114}$. The oil obtained from this plant also shows antioxidant properties to assist sperm parameters and enhance sperm quality in rats to increase spermatogenesis ${ }^{26}$. The antioxidant property is due to the polyphenoid rosmarinic acid which is a derivative of cinnamic acid ${ }^{32}$.

\subsection{Anti-Hyperlipidemic}

The aqueous $O$. basilicum extract significantly lowered both plasma triglycerides (TG) and cholesterol in acute hyperlipidemia induced by Triton WR-1339 in rats $^{102}$.

\subsection{Anticonvulsant}

Hydro distillation of aqueous leaf extract of Ocimum basilicum has strong anticonvulsant activity majorly due to the eugenol present in it $^{25}$.

\subsection{Anti-Inflammatory}

Solvent extraction of methanolic extract of Ocimum basilicum aerial parts have potent anti-inflammatory activity against macrophage (RAW264.7), human chondrosarcoma (SW1353) cell lines and human primary chondrocytes ${ }^{103}$.

\subsection{Antiplatelet}

The aqueous extract of Ocimum basilicum aerial parts was concentrated in a rotatory evaporator under vacuum at $65^{\circ} \mathrm{C}$ and studied against its antiplatelet activity using thrombint $(0.5 \mathrm{U} / \mathrm{ml})$ and $\mathrm{ADP}(5 \mu \mathrm{M})$ as agonists. It inhibits ADP-induced platelet aggregation by $13 \%$, $28.2 \%, 30.5 \%, 44.7 \%$ and $53 \%$ at a dose of $1,2,3,4$ and $5 \mathrm{~g} / \mathrm{l}$, respectively ${ }^{102}$.

\subsection{Anti-Thrombotic}

Platelet aggregation induced by ADP (5 AM) and thrombin (4 UI), and thrombus weight in an arteriovenous thrombosis (AVT) model were tested after 2 weeks treatment with 15,75 and $375 \mathrm{mg} / \mathrm{kg}$ OBL orally in rats, compared to $8.8 \mathrm{mg} / \mathrm{kg} /$ day aspirin Thrombininduced aggregation reached $33 \%, 22 \%, 21 \%$ for the aqueous extract of $O$. basilicum ${ }^{17}$. 


\subsection{Insecticidal Activity}

Usage of synthetic insecticides causes some significant consequences such as environmental pollution, pests or vector resistance and toxicity to other non-target creatures including human beings ${ }^{107}$. The vector mosquitoes are accomplished of communicating potential pathogens to human beings and them in charge for several infectious diseases like malaria, filariasis, Japanese encephalitis, yellow fever, dengue and chikungunya ${ }^{115}$. Moreover, the essential oil extract from the leaf $O$. basilicum was evaluated against Culex tritaeniorhynchus, Aedesal bopictus and Anopheles subpictus to predict the larvicidal activity ${ }^{116}$. It has its own significant effect against third stage larvae of Culex tritaeniorhynchus, Aedes albopictus and Anopheles subpictus with an $\mathrm{LC}_{50}$ and $9.75 \mathrm{ppm}$ and $\mathrm{LC}_{90}$ values of $23.44,21.17$ and $18.56 \mathrm{ppm}$ respectively ${ }^{97}$.

\subsection{Immunomodulatory}

The extracts from the plant Ocimum basilicum indicates its immunomodulatoryaction taking placein the cellularlevel, including platelet anti-aggregant property and inhibitory activity to counter HIV-1 reverse transcriptase ${ }^{106,33}$. The mechanisms underlying the hypolipidemic properties of Ocimum basilicum and anti-atherogenic potential of this plant at the cellular level is mysterious ${ }^{18}$.

\subsection{Cytotoxicity Effect}

The cytotoxicity effect of the active compounds (methyl cinnamate, linalool) of leaves extract of O. basilicum was performed by methyl thiazol tetrazolium (MTT) assay. In Table 3, the different concentration of extracts were affected the viability of human cancer cell line such as HeLa, HEp-2 and NIH 3T3 has been tabulated along with their $\mathrm{IC}_{50}$ value.

The HeLa and HEp-2 cells were grown in Eagles Minimum Essential Medium containing 10\% foetal bovine serum (FBS) and NIH 3T3 fibroblasts were grown in Dulbecco's Modified Eagles Medium containing 10\% FBS. For the screening experiment, the cells were seeded into 96 -well plates in $100 \mathrm{~mL}$ of the respective medium containing $10 \%$ FBS, at plating density of 10,000 cells per well, and incubated at $37^{\circ} \mathrm{C}, 5 \% \mathrm{CO} 2,95 \%$ air and $100 \%$ relative humidity for $24 \mathrm{~h}$. The essential oil was solubilized in dimethylsulphoxide (DMSO) and diluted in respective medium containing $1 \%$ FBS. After $24 \mathrm{~h}$, the
Table 3. $\quad I C_{50}$ value of different cancer cell lines

\begin{tabular}{llll}
\hline S. No & $\begin{array}{c}\text { Cancer cell line } \\
\text { type }\end{array}$ & $\begin{array}{c}\text { Parts of } \\
\text { the plant }\end{array}$ & $\mathbf{I C}_{50}(\boldsymbol{\mu g} / \mathbf{m L})$ \\
\hline 1 & HeLa $^{107}$ & Leaves & 90.0 \\
2 & MCF-7 $^{107,115}$ & Leaves & $260.3-270.3$ \\
3 & NIH $3 T 3$ mouse & Leaves & 120.7 \\
& $\begin{array}{l}\text { embryonic } \\
\text { fibroblasts }\end{array}$ & & \\
4 & Ln-CaP $^{107,115}$ & Leaves & $70.1-172$ \\
5 & P388 KB & \\
6 & HEp-1107 & Leaves & 36.2 \\
7 & EAC $^{109,115}$ & Leaves & 96.5 \\
\hline
\end{tabular}

medium was replaced with respective medium with $1 \%$ FBS containing the oil at various concentrations (12.5, $25,50,100,200$, and $300 \mathrm{mg} / \mathrm{mL}$ ) and incubated at the previously set parameters ${ }^{63-64}$. Triplicate was maintained and the medium without the oil served as control. After $48 \mathrm{~h}, 10 \mathrm{~mL}$ of MTT (5 mg/ 1mL) in phosphate-buffered saline was added to each well and incubated at $37 \mathrm{C}$ for $4 \mathrm{~h}$. The medium with MTT was then flicked off and the formed formazan crystals were solubilized in $100 \mathrm{~mL}$ of DMSO and absorbance was measured at $570 \mathrm{~nm}$ using microplate reader ${ }^{107}$.

\section{Diseases Affecting the O. basilicum $s p$}

Although various medicinal properties has been exhibited by $O$. basilicum, it also been affected by some diseases like wilt, mold, spot and rot. Most diseases occurs in leaves and stem of basil plants due to the infection of fungi. However it can be eradicated by using proper natural fungicide to maintain its original medical nature. Some of the diseases affecting basil are shown in Table 4 .

\section{Companies Manufacturing O. basilicum Products}

Basil products were commercially used all over the world for its nutritive purposes and medicinal values. Because of its multi dimensional use, many manufacturers produce basil products. Most of the basil products producing companies are located in Asian countries as shown in Table 5. 


\section{Adverse Effects and Caution}

Quercetin (a flavonoid) may be a co-carcinogen in bracken fern (Pteridium aquilinum). It has been suggested that it may interact with bovine papilloma

Table 4. Diseases affecting O. basilicum

\begin{tabular}{|c|c|c|c|c|}
\hline $\begin{array}{l}\text { SI. } \\
\text { No }\end{array}$ & $\begin{array}{l}\text { Disease } \\
\text { Name }\end{array}$ & $\begin{array}{l}\text { Parts of } \\
\text { the Plant }\end{array}$ & Symptoms & Causing agents \\
\hline 1. & $\begin{array}{l}\text { Fusarium } \\
\text { wilt }^{118}\end{array}$ & $\begin{array}{l}\text { Leaves } \\
\text { and stem }\end{array}$ & $\begin{array}{l}\text { Yellow and } \\
\text { wilting } \\
\text { leaves, } \\
\text { death of the } \\
\text { plant }\end{array}$ & $\begin{array}{l}\text { Fusarium } \\
\text { oxysporum } f \text {. }\end{array}$ \\
\hline 2. & $\begin{array}{l}\text { Gray } \\
\text { mold }^{119}\end{array}$ & $\begin{array}{l}\text { Leaves } \\
\text { and stem }\end{array}$ & $\begin{array}{l}\text { leaves } \\
\text { dying and } \\
\text { dropping } \\
\text { from plant }\end{array}$ & Botrytis cinerea \\
\hline 3. & $\begin{array}{l}\text { black } \\
\text { spot }^{120}\end{array}$ & $\begin{array}{l}\text { Leaves } \\
\text { and stem }\end{array}$ & $\begin{array}{l}\text { Black spots } \\
\text { on leaves }\end{array}$ & $\begin{array}{l}\text { Colletotrichum } \\
\text { gloeosporioides }\end{array}$ \\
\hline 4. & Basal rot ${ }^{121}$ & Leaves & $\begin{array}{l}\text { Wilting of } \\
\text { leaves }\end{array}$ & $\begin{array}{l}\text { Rhizoctonia } \\
\text { solani }\end{array}$ \\
\hline 5. & $\begin{array}{l}\text { Cercospora } \\
\text { leaf spot }{ }^{118}\end{array}$ & Leaves & $\begin{array}{l}\text { Circular to } \\
\text { irregular } \\
\text { dark spots } \\
\text { on leaves }\end{array}$ & $\begin{array}{l}\text { Cercospora } \\
\text { ocimicola }\end{array}$ \\
\hline 6. & $\begin{array}{l}\text { Downy } \\
\text { mildew }^{119}\end{array}$ & Leaves & $\begin{array}{l}\text { Yellowing } \\
\text { leaves }\end{array}$ & $\begin{array}{l}\text { Peronospora } \\
\text { belbahrii }\end{array}$ \\
\hline 7. & Leaf spot ${ }^{119}$ & Leaves & $\begin{array}{l}\text { streaks on } \\
\text { stems }\end{array}$ & $\begin{array}{l}\text { Pseudomonas } \\
\text { spp }\end{array}$ \\
\hline 8. & Root $\operatorname{rot}^{119}$ & Stem & $\begin{array}{l}\text { Failure of } \\
\text { seeds to } \\
\text { germinate }\end{array}$ & $\begin{array}{l}\text { Rhizoctonia } \\
\text { solani }\end{array}$ \\
\hline
\end{tabular}

Table 5. Companies manufacturing basil products

\begin{tabular}{|c|c|c|c|c|}
\hline S.No & Company Name & Country & Products & Source \\
\hline 1. & Global Merchants & India & Basil oil. & www.global-merchants.in/ \\
\hline 2. & Right Future International & India & $\begin{array}{l}\text { Leaves for flavoring } \\
\text { purpose. }\end{array}$ & www.rightfutureinternational.co.in/ \\
\hline 3. & Frontier Natural Products Co-op. & US & Basil leaf for flavors. & www.frontiercoop.com/ \\
\hline 4. & Haridass Aggarwal \& sons & India & Leaves for flavoring. & www.indiamart.com/haridas-agarwal-sons/ \\
\hline 5. & Natural Healthy concepts & India & Basil oils. & www.naturalhealthyconcepts.com/ \\
\hline 6. & $\begin{array}{l}\text { Zhongbei Northland Bio-chem } \\
\text { industry Co.Ltd. }\end{array}$ & China & $\begin{array}{l}\text { Basil oils for tonic } \\
\text { purpose. }\end{array}$ & http://daxinganlinglily.en.china.cn/ \\
\hline 7 & Jkh exports & India & $\begin{array}{l}\text { Leaves for aroma } \\
\text { products. }\end{array}$ & www.jkhexports.com/ \\
\hline 8. & Dujardin Foods Nv & Belgium & Basil oils. & www.dujardin-foods.com/ \\
\hline 9. & Jdg seeds company & India & Basil seeds. & www.jdgseeds.com/ \\
\hline 10. & Silver line Chemicals & India & Basil essential oils. & www.silverlinechemicals.com/ \\
\hline
\end{tabular}

virus type 4, leading to malignant epithelial papillomas ${ }^{122}$. Caffeic acid and P-coumaric acid (phenolic acids) may inhibit digestion of plant cell walls in ruminants, because of their antimicrobial activity. When these phenolic acids are metabolized by rumen microbes, benzoic acid, 3-phenylpropionic acid and cinnamic acid may be formed. On further detoxification, hippuric acid is formed. 3-phenylpropionic acid and hippuric acid can decrease metabolic efficiency and also decreases productivity. Safrole, which was used to flavor sodas, was banned as a food additive in the US because it has the potential to cause cancer in rats ${ }^{122}$. Moreover, it should not be used during pregnancies.

\section{Conclusion and Future Perspectives}

This review majorly focused on the distinctive pharmacological activities of $O$. basilicum and the specific extraction procedures for the chemical constituents present in it. Basil possesses anticonvulsant, anti-hyperlipidemic, anti-inflammatory, anti-oxidant, antiplatelet property, anti-thrombotic, anti-microbial, insecticidal, immunomodulatory and cytotoxicity activities. Moreover, it also delivers those chemical constituents which is very helpful for the sustainable development of drugs for human consume. Furthermore, it also speaks about some of the manufacturers of basil products. On the converse, basil also has some adverse 
effects, so it should be consumed with proper prescribed medications. In the future, research may make a transgenic basil plant to eradicate the environmental stress of the plant and to address a specific chemical constituent to act against various human diseases. Here we imaged the rough and trough of basil, so it will be very helpful for the future researcher to work in different dimensions of basil to make new products. O. basilicum is the important product of nature so "we would use and should protect it".

\section{Acknowledgement}

We thank American Cancer Society (ACS) for the reuse of Figure 2 in this review article. We also acknowledge Jaina Afrin Mohammed Farook of Department of Biotechnology, Periyar Maniammai Institute of Science \& Technology for her kind assistantship.

\section{Conflict of Interest}

There is no any conflict of interest among the authors.

\section{References}

1. Simon JE, Morales MR, Phippen WB, Vieira RF, Hao Z. Basil: A source of aroma compounds and a popular culinary and ornamental herb. Perspectives on New crops and new uses. Alexandria: ASHS Press. 1999.

2. Siddiqui BS, Bhatti HA, Begum S, Perwaiz S. Evaluation of the Anti-mycobacterium activity of the constituents from Ocimum basilicum against Mycobacterium tuberculosis. Journal of Ethnopharmacology. 2012; 144: 220-2. https://doi.org/10.1016/j.jep.2012.08.003 PMid:22982011

3. Bantis F, Ouzounis T, Radoglou K. Artificial LED lighting enhances growth characteristics and total phenolic content of Ocimum basilicum but variably affects transplant success. Scientia Horticulturae. 2016; 198: 277-83. https://doi.org/10.1016/j.scienta.2015.11.014

4. Snoussi M, Dehmani A, Noumi E, Flamini G, Papetti A. Chemical composition and antibiofilm activity of Petroselinum crispum and Ocimum basilicum essential oils against Vibrio spp. Strains. Microbial Pathogenesis. 2016; 90: 13-21.

5. Bora KS, Arora S, Shri R. Role of Ocimum basilicum L. in prevention of reperfusion induced cerebral damage, and motor dysfunctions in mice brain. Journal of Ethnopharmacology. 2011; 137: 1360-5. https://doi.org/10.1016/j.jep.2011.07.066 PMid:21843615
6. Loughrin JH, Kasperbauer MJ. Light reflected from colored mulches affects aroma and phenol content of sweet basil (Ocimum basilicum L.) Leaves. Journal of Agricultural and Food Chemistry. 2001; 49: 1331-5. https://doi.org/10.1021/jf0012648

7. Javanmardi J, Stushnoff C, Locke E, Vivanco JM. Antioxidant activity and total phenolic content of Iranian Ocimum accessions. Food Chemistry. 2003; 83: 547-50. https://doi.org/10.1016/S0308-8146(03)00151-1

8. Gulcin I, Elmastas M, Aboul-Enein HY. Determination of antioxidant and scavenging activity of Basil (Ocimum basilicum L. family lamiaceae) assayed by different methodologies. Phytotherapy Research. 2007; 21: 354-61. https://doi.org/10.1002/ptr.2069 PMid:17221941

9. Makinen S, Paakkonen K, Hiltunen R, Holm Y. Processing and use of basil in foodstuffs, beverages and in food preparation. Basil: the genus Ocimum. Netherlands: Harwood Academic Publishers. 1999.

10. Suppakul P, Miltz J, Sonneveld K, Bigger SW. Antimicrobial properties of basil and its possible application in food packaging. Journal of Agricultural and Food Chemistry. 2003; 51: 3197-207. https://doi.org/10.1021/jf021038t PMid:12744643

11. Nguyen PM, Niemeyer ED. Effects of nitrogen fertilization on the phenolic composition and antioxidant properties of basil (Ocimum basilicum L.). Journal of Agricultural and Food Chemistry. 2008; 56: 8685-91. https://doi.org/10.1021/jf801485u PMid:18712879

12. Chang SS, Ostric-Matijasevic B, Hsieh OAL, Huang CL. Natural antioxidant from rosemary and sage. Journal of Food Science. 1977; 42: 1102-7. https://doi.org/10.1111/j.1365-2621.1977.tb12676.x

13. Lachowicz KJ, Jones JP, Briggs DR, Bienvenu FE, Palmer MV, Mishra V, Hunter MM. Characteristics of Plants and Plant Extracts from Five Varieties of Basil (Ocimum basilicum L.) Grown in Australia. Journal of Agricultural and Food Chemistry. 1997; 45(7): 2660-5. https://doi.org/10.1021/jf960791h

14. Khazaeia N, Esmaiilia M, Djomehb ZE, Ghasemlouc M, Joukid M. Characterization of new biodegradable edible film made from basil seed (Ocimum basilicum L.) gum. Carbohydrate Polymers. 1997; 102: 199-206. https://doi.org/10.1016/j.carbpol.2013.10.062 PMid:24507273

15. Marotti M, Piccaglia R, Giovanelli E. Differences in essential oil composition of basil (Ocimum basilicum L.) Italian cultivars related to morphological characteristics. Journal of Agricultural and Food Chemistry. 1996; 44: 3926-9. https://doi.org/10.1021/jf9601067 
16. Zheljazkov VD, Cantrell CL, Tekwani B, Khan SI. Content, composition, and bioactivity of the essential oils of three basil genotypes as a function of harvesting. Journal of Agricultural and Food Chemistry. 2008; 56: 380-5. https://doi.org/10.1021/jf0725629 PMid:18095647

17. Tohti I, Tursun M, Umar A, Turddi S, Imin H, Nicholas M. Aqueous extracts of Ocimum basilicum L. (Sweet basil) decrease platelet aggregation induced by ADP and thrombin in vivo arteriovenous shunt thrombosis in vivo. Thrombosis Research. 2006; 118: 733-9. https://doi.org/10.1016/j.thromres.2005.12.011 PMid:16469363

18. Bravo E, Amrani S, ArizM, Harnafi H, Napolitano M. Ocimum basilicum ethanolic extract decreases cholesterol synthesis and lipid accumulation in human macrophages. Fitoterapia. 2008; 79: 515-23. https://doi.org/10.1016/j.fitote.2008.05.002 PMid:18620033

19. Libera Z, Carovic-Stanko K, Politeoc O, Strikic F, Kolak I, Milos M, Satovic Z: Chemical Characterization and Genetic Relationships among Ocimum basilicum L. Cultivars. Chemistry \& Biodiversity. 2011; 8(11): 1978-89. https://doi.org/10.1002/cbdv.201100039 PMid:22083911

20. Rai V, Mani UV, Iyer UM. Effect of Ocimum sanctum leaf powder on blood lipoproteins, glycated proteins and total Amino acids in patients with Non-insulin-dependent Diabetes Mellitus. Journal of Nutritional \& Environmental Medicine. 2009; 7: 113-8.

21. Harnafia H, Azizb M, Amrania S. Sweet basil (Ocimum basilicum L.) improves lipid metabolism in hypercholesterolemic rats. The European e-Journal of Clinical Nutrition and Metabolism. 2009; 4: 181-6. https://doi.org/10.1016/j.eclnm.2009.05.011

22. Umar A, Zhou W, Abdusalam E, Tursun A, Reyim N, Tohti I, MooreN.Effect ofOcimumbasilicumL.on cyclo-oxygenase isoforms and prostaglandins involved in thrombosis. Journal of Ethnopharmacology. 2014; 152: 151-5. https://doi.org/10.1016/j.jep.2013.12.051 PMid:24412551

23. Tsai KD, Lin BR, Perng DS, Wei JC, Yu YW, Cherng JM: Immunodulatory effects of aqueous extract of Ocimum basilicum (Linn.) and some of its constituents on human immune cells. Journal of Medicinal Plants Research. 2011; 5: 1873-83.

24. Opalchenova G, Obreshkova D. Comparative studies on the activity of basil-an essential oil from Ocimum basilicum L. against multidrug resistant clinical isolates of the genera Staphylococcus and Pseudomonas by using different test methods. Journal of Microbiological Methods. 2003; 54: 105-10. https://doi.org/10.1016/S0167-7012(03)00012-5

25. Freire MM, Marques OM, Costa M. Effects of seasonal variation on the central nervous system activity of Ocimum gratissimum L. essential oil. Journal of Ethnopharmacology. 2006; 105: 161-6. https://doi.org/10.1016/j.jep.2005.10.013 PMid:16303272

26. Khalil A. Antimicrobial activity of ethanolic extracts of Ocimum basilicum leaf from Saudi Arabia. Biotechnology. 2013; 12: 61-4. https://doi.org/10.3923/biotech.2013.61.64

27. Hassanpouraghdam MB, Hassani A, Vojodi L, Farsadakhtar N. Drying Method Affects Essential Oil Content and Composition of Basil (Ocimum basilicum L.). Journal of Essential Oil Bearing Plants. 2010; 13: 759-66.

28. Aishwath OP, Nibauria SV. Utilization of problematic soil and water resources through aromatic plants. Ecology, Environment and Conservation. 2009; 15(4): 715-24.

29. Alves-Silvaa JM, Dias dos Santosa SM, Pintadob ME, Perez-Alvarezc JA, Fernandez-Lopezc J, ViudaMartosc M. Chemical composition and in vitro antimicrobial, antifungal and antioxidant properties of essential oils obtained from some herbs widely used in Portugal. Food Control. 2013; 32: 371-8. https://doi.org/10.1016/j.foodcont.2012.12.022

30. Radulovic NS, Blagojevic PD, Miltojevic AB. $\alpha$-Linalool marker compound of forged/synthetic sweet basil (Ocimum basilicum L.) essential oils. Journal of the Science of Food and Agriculture. 2013; 93: 3292-303. https://doi.org/10.1002/jsfa.6175 PMid:23584979

31. Lee J, Scagel CF. Chicoric acid found in basil (Ocimum basilicum L.) leaves. Food Chemistry. 2009; 115: 650-6. https://doi.org/10.1016/j.foodchem.2008.12.075

32. Phippen WB, Simon JE. Anthocyanins in basil (Ocimum basilicum L.). Journal of Agricultural and Food Chemistry. 1998; 46: 1734-8. https://doi.org/10.1021/jf970887r

33. Yamasaki K, Nakano M, Kawahata T, Mori H, Otake T, Ueba N, Oishi I, Inami R, Yamane M, Nakamura M, et al., Anti-HIV-1 activity of herbs in Labiatae. Biological and Pharmaceutical Bulletin. 1998; 21: 829-33. https://doi.org/10.1248/bpb.21.829 PMid:9743251

34. Galhiane MS, Rissato SR, Chierice GO, Almeida MV, Silva LC. Influence of different extraction methods on the yield and linalool content of the extracts of Eugenia uniflora L. Talanta. 2006; 70(2): 286-92. https://doi.org/10.1016/j.talanta.2006.02.040 PMid:18970765 
35. Kim YK, Lee HS, Min SS, Seol GH. Neuroprotective Effect of (-)-Linalool against sodium nitroprusside induced cytotoxicity. Medicinal Chemistry. 2015; 5(4): 178-82.

36. Khalil AA, Rahman U, Khan MR, Sahar A, Mehmoodac T, Muneeb Khana. Essential oil eugenol: sources, extraction techniques and nutraceutical perspectives. RSC Advances. 2017; 7(52): 32669-81.

37. Pramod K, Ansari SH, Ali J. Eugenol: a natural compound with versatile pharmacological actions. Natural Product Communications. 2010; 5(12): 1999-2006. PMid:21299140

38. Wu H, Hendrawinata W, Yu Y, Gao X, Li Y, Bartle J, Grayling P. Effect of Hydro distillation on 1,8-Cineole Extraction from Mallee leaf and the fuel properties of spent biomass. Industrial \& Engineering Chemistry Research. 2011; 50(19): 11280-7. https://doi.org/10.1021/ie201092h

39. Rocha Caldas GF, Silva Oliveira AR, Araujo AV, Lopes Lafayette SS, Albuquerque GS, Silva-Neto JC, et.al. Gastroprotective Mechanisms of the Monoterpene 1,8-Cineole (Eucalyptol). PLoS ONE. 2015; 10(8): 134558. https://doi.org/10.1371/journal.pone.0134558 PMid:26244547 PMCid:PMC4526535

40. Benitez PN, Leon MEM, Stashenko EE. Eugenol and methyl eugenol chemotypes of essential oil of species Ocimum gratissimum L. and Ocimum campechianum from Colombia. Journal of Chromatographic Science. 2009; 47(9): 800-3. https://doi.org/10.1093/chromsci/47.9.800

41. Ding J, Huang C, Peng Z, Xie Y, Deng S, Nie YZ, Xu TL, Ge WH, Li WG, Li F. Electrophysiological characterization of methyleugenol: a novel agonist of GABA (A) receptors. ACS Chemical Neuroscience. 2014; 5(9): 803-11. https://doi.org/10.1021/cn500022e PMid:24980777

42. Lopresto CG, Petrillo F, Casazza AA, Aliakbarian B, Perego P, Calabro V. A non-conventional method to extract D-limonene from waste lemon peels and comparison with traditional Soxhlet extraction. Separation and Purification Technology. 2014; 137: 13-20.

43. Vale TG, Furtado EC, Santos JG, Viana GS. Central effects of citral, myrcene and limonene, constituents of essential oil chemotypes from Lippia alba (Mill). Phytomedicine. 2002; 9(8): 709-14. https://doi.org/10.1078/094471102321621304

44. Hui-Ping W, Mu Z, Yong L, Weng-Quan L. Extraction and isolation of $\beta$-elemene from Eupatorium adenophorum. Journal of Chemical and Pharmaceutical Research. 2014; 6(5): 161-5.
45. Quentin Li Q, Wang G, Huang F, Banda M, Reed E. Antineoplastic effect of $\beta$-elemene on prostate cancer cells and other types of solid tumour cells. Journal of Pharmacy and Pharmacology. 2010; 62(8): 1018-27. https://doi.org/10.1111/j.2042-7158.2010.01135.x PMid:20663036

46. Jadhav NM, Thergaonkar RS, Deodhar MA. Extraction of essential oil from flowers of mesua ferrea linn. Gcms analysis and incorporation in cosmetic product. International Journal of Pharmaceutical Sciences and Research. 2016; 7(12): 5106-10.

47. Palmer-Young EC, Veit D, Gershenzon J, Schuman MC. The Sesquiterpenes (E)- $\beta$-Farnesene and (E)- $\alpha-$ Bergamotene quench ozone but fail to protect the wild Tobacco nicotiana attenuate from ozone, UVB, and Drought Stresses. PLoS ONE. 2015; 10(6): e0127296. https://doi.org/10.1371/journal.pone.0127296 PMid:26030663 PMCid:PMC4452144

48. Fan S, Chang J, Zong Y, Hu G, Jia J. GC-MS analysis of the composition of the essential oil from Dendranthema indicum Var. Aromaticum using three extraction methods and two columns. Molecules. 2018; 23(3): 576. https:// doi.org/10.3390/molecules 23030576 PMid:29510531 PMCid:PMC6017652

49. Wu X, Xiao F, Zhang Z, Li X, Xu Z. Research on the analgesic effect and mechanism of bornyl acetate in volatile oil from Amomum villosum. Zhong Yao Cai. 2005; 28(6): 505-7. PMid:16209271

50. Alvi MN, Ahmad S, Rehman K. Short communication preparation of menthol crystals from mint (Mentha arvensis). International Journal of Agriculture and Biology. 2001; 3(4): 527-8.

51. Galeotti N, Ghelardini C, Cesare Mannelli LD, Mazzanti G, Baghiroli L, Bartolini A. Local anaesthetic activity of (+)- and ( \pm )-Menthol. Planta Medica. 2001; 67: 174-6. https://doi.org/10.1055/s-2001-11515 PMid:11301871

52. Nozala MJ, Bernala JL, Jimeneza JJ, Gonzaleza MJ, Higes M. Extraction of thymol, eucalyptol, menthol, and camphor residues from honey and beeswax: Determination by gas chromatography with flame ionization detection. Journal of Chromatography A. 2002; 954(1-2): 207-15. https://doi.org/10.1016/S0021-9673(02)00153-X

53. Zuccarini P. Camphor: risks and benefits of a widely used natural product. Journal of Applied Sciences and Environmental Management. 2009; 13(2): 69-74.

54. Tam CU, Yang FQ, Zhang QW, Guan J, Li SP. Optimization and comparison of three methods for extraction of volatile compounds from Cyperus 
rotundus evaluated by gas chromatographymass spectrometry. Journal of Pharmaceutical and Biomedical Analysis. 2007; 44(2): 444-9. https://doi.org/10.1016/S0021-9673(02)00153-X PMid:17127024

55. Turkez H, Celik K, Togar B. Effects of copaene, a tricyclic sesquiterpene, on human lymphocytes cells in vitro. Cytotechnology. 2013; 66(2014): 597-603. https://doi.org/10.1007/s $10616-013$-9611-1 PMid:24287609 PMCid:PMC4082788

56. Quispe-Condori S, Foglio MA, Rosa PTV, Meirelesa MAM. Obtaining $\beta$-caryophyllene from Cordia verbenacea de Candolle by supercritical fluid extraction. The Journal of Supercritical Fluids. 2008; 46(1): 27-32.

57. Legault J, Pichette A. Potentiating effect of betacaryophyllene on anticancer activity of alphahumulene, isocaryophyllene and paclitaxel. Journal of Pharmacy and Pharmacology. 2007; 59(12): 1643-7. https://doi.org/10.1211/jpp.59.12.0005 PMid:18053325

58. Lekar AV, Borisenko SN, Filonova OV, Vetrova EV, Maksimenko EV, Borisenko NI, Minkin VI. Extraction of caftaric and cichoric acids from Echinacea purpurea L. in subcritical water. Russian Journal of Physical Chemistry B. 2013; 7(8): 968-75. https://doi.org/10.1134/S199079311308006X

59. Kuban-Jankowska A, Sahu KK, Gorska M, Tuszynski JA, Wozniak M. Chicoric acid binds to two sites and decreases the activity of the YopH bacterial virulence factor. Oncotarget. 2016; 7(3): 2229-38. https:/doi.org/10.18632/oncotarget.6812 PMid:26735581 PMCid:PMC4823031

60. Green CP, Osborne P. Rapid methods for obtaining essential oil from hops. Journal of the Institute of Brewing. 1993; 99: 335-9. https://doi.org/10.1002/j.2050-0416.1993.tb01172.x

61. Sun Y, Qiao H, Ling Y, Yang S, Rui C, Pelosi P, Yang X. New Analogues of (E)- $\beta$-Farnesene with insecticidal activity and binding affinity to aphid odorant binding proteins. Journal of Agricultural and Food Chemistry. 2011; 59(6):2456-61. https://doi.org/10.1021/jf104712c PMid:21341697

62. Marzouki H, Piras A, Marongiu B, Rosa A, Dessì MA. Extraction and separation of volatile and fixed oils from berries of Laurus nobilis $L$. by supercritical $\mathrm{CO}_{2}$. Molecules 2008; 13: 1702-11. https://doi.org/10.3390/molecules 13081702 PMid:18794780 PMCid:PMC6245310
63. Cascaes MM, Skelding Pinheiro Guilhon GM, Aguiar rade EH, Bichara Zoghbi MG, Silva Santos L. Constituents and pharmacological activities of Myrcia (Myrtaceae): A review of an aromatic and medicinal group of plants. International Journal of Molecular Sciences. 2015; 16: 23881-904. ht tps://doi.org/10.3390/ijms 161023881 PMCid:PMC4632730

64. Rohloff J. Monoterpene composition of essential oil from peppermint (Mentha piperita L.) with regard to leaf position using solid phase microextraction and Gas Chromatography/Mass Spectrometry Analysis. Journal of Agricultural and Food Chemistry. 1999; 47 (9): 3782-6. https://doi.org/10.1021/jf981310s PMid:10552722

65. Muftah RS, Shushni Asma Belkheir AM. Antibacterial and antioxidant activities of Mentha piperita L. Arabian Journal of Chemistry. 2015; 8(3): 322-8. https://doi.org/10.1016/j.arabjc.2011.01.019

66. Noge K, Becerra JX. Germacrene D, A common sesquiterpene in the Genus Bursera (Burseraceae). Molecules. 2009; 14:5289-97. https:// doi.org/10.3390/molecules 14125289 PMid:20032892 PMCid:PMC6255432

67. Del-Vechio-Vieira G, Vieira de Sousa O, Miranda MA, Senna-Valle L, Coelho Kaplan MA. Analgesic and anti-inflammatory properties of essential oil from Ageratum fastigiatum. Brazilian Archives of Biology and Technology. 2009; 52(5): 1115-21. https://doi.org/10.1590/S1516-89132009000500008

68. SilvErio MS, Del-Vechio-Vieira G, Pinto MAO, Alves MS, Sousa OV. Chemical composition and biological activities of essential oils of Eremanthus erythropappus McLeisch (Asteraceae). Molecules. 2013; 18: 9785-96. https://doi.org/10.3390/molecules 18089785 PMid:23959191

69. Han GH, Kim SK, Kyung Seok Yoon P, Kang Y, Kim BS, Fu Y. Fermentative production and direct extraction of (-)- $\alpha$-bisabolol in metabolically engineered Escherichia coli. Microbial Cell Factories. 2016; 15: 185. https://doi.org/10.1186/s 12934-016-0588-2 PMid:27825357 PMCid:PMC5101696

70. Queiroz A, Cajaiba J. A sustainable process for (-)-a-bisabolol extraction from Eremanthus erythropappus using supercritical $\mathrm{CO}_{2}$ and ethanol as co-solvent. The Journal of Supercritical Fluids. 2015; 110: 39-46. https://doi.org/10.1016/j.supflu.2015.12.011

71. Kamatou GPP, Viljoen AM. A review of the application and pharmacological properties of $\alpha$-Bisabolol and $a$-Bisabolol rich oils. Journal of the 
American Oil Chemists' Society. 2010; 87(1): 1-7. https://doi.org/10.1007/s11746-009-1483-3

72. Naseem MK, Younis A, Khan MA, Ahmad R. Gas chromatography-mass spectrometry of Murraya exotica essential oil extracted through different extraction techniques. The Journal of Animal \& Plant Sciences. 2015; 25(6): 1730-6.

73. Muley BP, Khadabadi SS, Banarase NB. Phytochemical constituents and pharmacological activities of Calendula officinalis L. (Asteraceae): A review. Tropical Journal of Pharmaceutical Research. 2009; 8(5): 455-65. https://doi.org/10.4314/tjpr.v8i5.48090

74. Nekoei M, Mohammad hosseini M. Chemical composition of the essential oils and volatiles of Salvia leriifolia by three different extraction methods prior to Gas Chromatographic-Mass Spectrometric determination: Comparison of HD with SFME and HS-SPME. Journal of Essential Oil Bearing Plants. 2017; 20(2): 410-25. https://doi.org/10.1080/0972060X.2017.1305918

75. Scura MC, Pintoa FGS, Pandini JA, Costa WF, Leite CW, Temponi LG. Antimicrobial and antioxidant activity of essential oil and different plant extracts of Psidium cattleianum Sabine. Brazilian Journal of Biology. 2016; 76(1): 101-8. https://doi.org/10.1590/1519-6984.13714PMid:26871744

76. Andrade TCB, Lima SG, Freitas RM, Rocha MS, Islam $\mathrm{T}$, Silva $\mathrm{TG}$, et al. Isolation, characterization and evaluation of antimicrobial and cytotoxic activity of estragole, obtained from the essential oil of Croton zehntneri (euphorbiaceae). Anais da Academia Brasileira de Ciencias. 2015; 87(1): 173-82. https://doi.org/10.1590/0001-3765201520140111 PMid:25789792

77. Silva-Alves KS, Ferreira-da-Silva FW, Peixoto-Neves D, Viana-Cardoso KV, Moreira-Junior L, Oquendo MB. Estragole blocks neuronal excitability by direct inhibition of $\mathrm{Na}+$ channels. Brazilian Journal of Medical and Biological Research. 2013; 46(12): 1056-63. https://doi.org/10.1590/1414-431X20133191 PMid:24345915 PMCid:PMC3935278

78. Manuale DL, Betti C, Juan C, Yori JM. Synthesis of liquid menthol by hydrogenation of dementholized peppermint oil over Ni catalysts. Quimica Nova. 2010; 33(6): 1231-4. https://doi.org/10.1590/S0100-40422010000600002

79. Eccles R, Griffiths DH, Newton CG, Tolley NS. The effects of menthol isomers on nasal sensation of airflow. Clinical Otolaryngology. 1988; 13(1): 25--9. https://doi.org/10.1111/j.1365-2273.1988.tb00277.x PMid:3370851
80. Gakuubi MM. Steam distillation extraction and chemical composition of essential oils of Toddalia asiatica L. and Eucalyptus camaldulensis Dehnh. Journal of Pharmacognosy and Phytochemistry. 2016; 5(2): 99-104.

81. Swamy MK, Sinniah UR. A comprehensive review on the phytochemicalconstituentsand pharmacological activities of Pogostemon cablin Benth.: An aromatic medicinal plant of industrial importance. Molecules. 2015; 20: 8521-47. https://doi.org/10.3390/molecules2 0058521 PMid:25985355

82. Alshishani AA, Saad B, Semail NF, Salhimi SM, Mohd Talib MK. Salting-out assisted liquid-liquid extraction method coupled to gas chromatography for the simultaneous determination of thujones and pulegone in beverages. International Journal of Food Properties. 2017; 20(3): 2776-85. https://doi.org/10.3390/molecules20058521

83. Sousaa DP, Nobrega FFF, Lima MRV, Almeida RN. Pharmacological activity of (R)-(+)Pulegone, A chemical constituent of essential oils. Zeitschrift fur Naturforschung C. 2011; 66: 353-9. https://doi.org/10.1515/znc-2011-7-806

84. Sarwan B, Pare B, Acharya AD, Jonnalagadda SB. Mineralization and toxicity reduction of textile dye neutral red in aqueous phase using Bioclphotocatalysis. Journal of Photochemistry and Photobiology B: Biology. 2012; 166: 48-55. https://doi.org/10.1016/j.jphotobiol.2012.07.006 PMid:22964463

85. Gosavi VD, Sharma S. A general review on various treatment methods for textile wastewater. JECET: Journal of Environmental Science, Computer Science and Engineering and Technology. 2013; 3: 29-39.

86. Solanki M, Suresh S, Das SN, Shukla K. Treatment of real textile wastewater using coagulation technology. International Journal of ChemTech Research. 2013; 5: 610-5.

87. Yin CY. Emerging usage of plant-based coagulants for water and wastewater treatment. Process Biochemistry. 2010; 45: 1437-44. https://doi.org/10.1016/j.procbio.2010.05.030

88. Sciban M, Klasnja M, Antov M, Skrbic B. Removal of water turbidity by natural coagulants obtained from chestnut and acorn. Bioresource Technology. 2010; 100: 6639-43. https://doi.org/10.1016/j.biortech.2009.06.047 PMid:19604691

89. Gupta A, Karjikar M, Nair J. Biosorption of copper using mucilaginous seeds of Ocimum basilicum. Acta Biologica Indica. 2010; 1: 113-9. 
90. Melo JS, souza SF. Removal of chromium by mucilaginous seeds off Ocimum basilicum. Bioresource Technology. 2004; 92: 151-5. https://doi.org/10.1016/j.biortech.2003.08.015 PMid:14693447

91. Sahay R, patra DD. Identification and performance of sodicity tolerant phosphate solubilizing bacteria isolates on Ocimum basilicumin sodic soil. Ecological Engineering. 2014; 71: 639-43. https://doi.org/10.1016/j.ecoleng.2014.08.007

92. Klimankova E, Holadova K, Hajslova J, Cajkaa K, Poustka J, Koudela M. Aroma profiles of five basil (Ocimum basilicum L.) cultivars grown under conventional and organic conditions. Food Chemistry. 2001; 107: 464-72. https://doi.org/10.1016/j.foodchem.2007.07.062

93. WerkerE,PutievskyE, RavidU,DudaiN,KatzirI.Glandular hairs and essential oil in developing leaves of Ocimum basilicumL. (Lamiceae). Annals of Botany. 2001;71:43-50. https://doi.org/10.1006/anbo.1993.1005

94. Govindarajan $\mathrm{M}$, Sivakumar R, Rajeswary M, Yogalakshmi K. Chemical composition and larvicidal activity of essential oil from Ocimum basilicum (L.) against Culex tritaeniorhynchus, Aedesalbopictus and Anopheles subpictus (Diteria: culicidae). Experimental Parasitology. 2013; 134: 7-11. https://doi.org/10.1016/j.exppara.2013.01.018 PMid:23391742

95. Zeggwagh N, Sulpice A, Eddouks TM. Antihyperglycaemic and hypolipidemic effects of Ocimum basilicum aqueous extract in diabetic rats. American Journal of Pharmacology and Toxicology. 2007; 2: 123-9. https://doi.org/10.3844/ajptsp.2007.123.129

96. Nyugen PM, Kwee EM, Niemeyer ED. Potassium rate alters the antioxidant capacity and phenolic concentration of basil (Ocimum basilicum L.) leaves. Food Chemistry. 2010; 123: 1235-41. https://doi.org/10.1016/j.foodchem.2010.05.092

97. Hossain MA, Kabir MJ, Salehuddin SM, Das AK, Singha SK, Alam MK, Rahman A. Antibacterial properties of essential oils and methanol extracts of sweet basil Ocimum basilicum occurring in Bangladesh. Pharmaceutical Biology. 2010; 5: 504-11. https://doi.org/10.3109/13880200903190977 PMid:20645791

98. Kim HJ, Chen F, Wang X, Rajapakse NC. Effect of chitosan on the biological properties of sweet basil (Ocimum basilicum L.). Journal of Agricultural and Food Chemistry. 2005; 53: 3696-701. https://doi.org/10.1021/jf0480804 PMid:15853422
99. Ozcan M, Chalchat JC. Essential oil of Ocimum basilicum L. and Ocimum minimum L, in turkey. Journal of Food Science. 2005; 20: 223-8.

100. Sethuraman J, Nehru H, Shanmugam K, Balakrishnanan P. Evaluation of potent phytochemicals and antidiabetic activity of Ficus racemose L. World Journal of Pharmaceutical Research. 2017; 6(15): 909-20.

101. Ramalingam PS, Sagayaraj M, Ravichandiran P, Balakrishnanan P, Nagarasan S, Shanmugam K. Lipid peroxidation and anti-obesity activity of Nigella sativa seeds. World Journal of Pharmaceutical Research. 2017; 6(10): 882-92.

102. Amrani S, Harnafi H, Gadi D, Mechfi H, Legssyer A, Ariz M, Martin-Nizard F, Bosca L.: Vasorelaxant antiplatelet aggregation effects of aqueous Ocimum basilicum extract. Journal of Ethnopharmacology. 2009; 125: 157-62. https://doi.org/10.1016/j.jep.2009.05.043 PMid:19505553

103. Raina P, Deepak M, Chandrasekaran CV, Agarwal A, Wagh N, Kaul-Ghanekar R. Comparative analysis of anti-inflammatory activity of aqueous and methanolic extracts of Ocimum basilicumin RAW 264.7, SW1353 and human primary chondrocytes. Journal of Herbal Medicine. 2016; 6(1): 28-36. https://doi.org/10.1016/j.hermed.2016.01.002

104. Pandey V, Patel A, Patra DD. Integrated nutrient regimes ameliorate crop productivity, nutritive value, antioxidant activity and volatiles in basil (Ocimum basilicum L.). Industrial Crops and Products. 2016; 87: 124-31. https://doi.org/10.1016/j.indcrop.2016.04.035

105. Flanigan PM, Niemeyer ED. Effect of cultivar on phenolic levels, anthocyanin composition, and antioxidant properties in purple basil (Ocimum basilicum L.). Food Chemistry. 2014; 164: 518-26. https://doi.org/10.1016/j.foodchem.2014.05.061 PMid:24996365

106. Okazaki K, Nakayama S, Kawazoe K, Takaishi Y. Anti-aggregant effects on human platelets of culinary herbs. Phytotherapy Research. 2011; 12: 603-5. h t t p s : / / d o i.org / 10.1002 / ( S I C I ) 1099 1573(199812)12:8<603::AID-PTR372>3.0.CO;2-G

107. Aarthi N, Murugan K. Larvicidal and repellent activity of Vetiveri azizanioides L, Ocimum basilicum L and the microbial pesticide spinosad against malarial vector, Anopheles 76 stephensi Liston (Insecta: Diptera: Culicidae). Journal of Biopesticides. 2010; 3: 199-204.

108. Davies J. Inactivation of antibiotics and the dissemination of resistance genes. Science. 1994; 64: 375-82. https://doi.org/10.1126/science.8153624 
109. FaleiroJR, El-Saad MA, Al-Abbad AH. Pheromone trap density to mass trap Rhynchophorus ferrugineus (Coleoptera: Curculionidae/Rhynchophoridae/ Dryophthoridae) in date plantations of Saudi Arabia. International Journal of Tropical Insect Science. 2011; 31: 75-7. https://doi.org/10.1017/S1742758411000099

110. Basilico MZ, Basilico JC. Inhibitory effects of some spice essential oils on Aspergillus ochraceus NRRL 3174 growth and ochratoxin. A production. Letters in Applied Microbiology. 1999; 29: 238-41. https://doi.org/10.1046/j.1365-2672.1999.00621.x PMid:10583751

111. BaisHP,WalkerTS, SchweizerHP,VivancoJM.Rootspecific elicitation and antimicrobial activity of rosmarinic acid in hairy root cultures of sweet basil (Ocimum basilicum L.). Plant Physiology and Biochemistry. 2002; 40: 983-95. https://doi.org/10.1016/S0981-9428(02)01460-2

112. Kumar A, Shukla R, Singh P, Prakash B, Dubey NK. Chemical composition of Ocimum basilicum L. essential oil and its efficacy as a preservative against fungal and aflotaxin contamination of dry fruits. International Journal of Food Science and Technology. 2011; 46: 1840-6.

113. Oxenham SK, Svoboda KP, Walters DR. Antifungal activity of the essential oil of basil (Ocimum basilicum). Journal of Phytopathology. 2005; 153: 174-80. https://doi.org/10.1111/j.1439-0434.2005.00952.x

114. Marinava EM, Ynishlieva NV. Antioxidative activity of extracts from selected species of the family of Lamiaceae in sunflower oil. Food Chemistry. 1997; 58: 245. https://doi.org/10.1016/S0308-8146(96)00223-3

115. Nauen R. Insecticide resistance in disease vectors of public health importance. Pest Management Science. 2007; 63: 628-33. https://doi.org/10.1002/ps.1406 PMid:17533649

116. Kathirvel P, Ravi S. Chemical composition of the essential oil from basil (Ocimum basilicum Linn.) and its in vitro cytotoxicity against HeLa and HEp-2 human cancer cell lines and NIH 3T3 mouse embryonic fibroblasts. Natural Product Research. 2012; 26: 1112-8. https://doi.org/10.1080/14786419.2010.545357 PMid:21939371

117. Hussain AI, Anwar F, Sherazi STH, Przybylski R. Chemical composition, antioxidant and antimicrobial activities of basil (Ocimum basilicum) essential oils depend on seasonal variations. Food Chemistry. 2008; 108: 986-95. https://doi.org/10.1016/j.foodchem.2007.12.010 PMid:26065762

118. Taie, NA, Salama, ZA, Radwan S. Potential activity of basil plants as a source of antioxidants and anticancer agents as affected by organic and Bio-organic fertilization. Notulae Botanicae Horti Agrobotanici Cluj-Napoca. 2010; 38: 119-27.

119. TranT.BasilDiseases.CornellUniversityDepartmentofPlant Pathology and Plant-Microbe Biology. 2011. Available from: http://plantclinic.cornell.edu/factsheets/basildiseases.pdf.

120. CABI Crop Protection Compendium. Ocimum basilicum datasheet. 2008. Available from: http://www.cabi.org/cpc/datasheet/36858.

121. Gamliel A, Yarden O. Diversification of diseases affecting herb crops in Israel accompanies the increase in herb crop production. Phytoparasitica. 1998; 26: 53. https://doi.org/10.1007/BF02981266

122. Araldi RP, Assaf SMR, Carvalho RF, Caldas MA, Carvalho R, Souza JM, Magnelli RF, Modolo GD, Roperto FP, Stoccol C and Becak W. Papillomaviruses: a systematic review. Genetics and Molecular Biology. 2017; 40(1): 1-21. https://doi.org/10.1590/1678-4685-gmb-2016-0128 PMid:28212457 PMCid:PMC5409773

121. Gamliel A, Yarden O. Diversification of diseases affecting herb crops in Israel accompanies the increase in herb crop production. Phytoparasitica. 1998; 26: 53. https://doi.org/10.1007/BF02981266

122. Araldi RP, AssafSMR, Carvalho RF, Caldas MA, Carvalho R, Souza JM, Magnelli RF, Modolo GD, Roperto FP, Stocco1 C and Becak W. Papillomaviruses: a systematic review. Geneticsand Molecular Biology.2017;40(1):1-21. https://doi.org/10.1590/1678-4685-gmb-2016-0128. PMid:28212457 PMCid:PMC5409773 